\title{
COMPRESSIVE STRENGTH OF STRUCTURAL TILE MASONRY
}

\author{
By Douglas E. Parsons and David Watstein
}

\section{ABSTRACT}

In cooperation with the Housing Division of the Federal Emergency Administration of Public Works, 6 walls and 30 wallettes were tested. The object was to determine how differences in tile design or kind of mortar affected the compressive strength of masonry walls in a combination of brick-facing and endconstruction tile under eccentric loads. The walls were of structural clay tile with a facing of brick, alike in all respects except design of the tile. Different mortars as well as tiles of different designs were used in constructing the wallettes. All masonry specimens were tested at the age of 2 months.

As the loads were applied on the walls during the compressive tests, the rate of deformation increased with increasing loads, because of the yielding of the mortar. The mortar, composed of a mixture of one part cement, one part lime, and six parts of sand, by volume, crushed in the bed joints for the tile. The strengths of the walls were roughly proportional to the thickness of the face shells of the tiles. The crushing of the mortar in the bed joints also was the first sign of impending failure of the wallettes, except for those built with mortars rich in portland cement.

I. Introduction

II. Materials

1. Tiles_._.

2. Bricks

3. Mortars

III. Walls and wallettes

1. Description of walls

(a) Types..... 219

(b) Workmanship

(c) Aging

2. Description of wallettes

(a) Types . .

(b) Aging

3. Methods of testing

(a) Walls $\ldots$

(b) Wallettes

IV. Results of the tests with discussion

1. Walls

(a) Stress-strain diagrams

(b) Behavior under load.

(c) Compressive strength

2. (d) Effect of kind of tile on the strength of the walls

(a) Behavior under load 24

(b) Compressive strength _. _.

V. Conclusions 


\section{INTRODUCTION}

At the request of the Housing Division, Federal Emergency Administration of Public Works, the National Bureau of Standards tested 6 walls and 30 wallettes to determine the effects of differences in either the design of the tile or the kind of mortar on the compressive strength of tile masonry. The six walls were of structural clay tile with facings of brick; they were similar in all respects except the design of the tiles, there being two walls each of three different kinds of tile. The wallettes included three each of seven kinds of tile and one mortar, and three each of four kinds of mortar with the same type of tile.

\section{MATERIALS}

\section{TILES}

The designs of the tiles are illustrated in figures 1 and 2 ; figure 1 shows end views of stretcher tiles, and figure 2 illustrates both stretcher and bonding tiles. All of the tiles were made from fire clay. Powdered coal was mixed with the clay used in forming the lightweight tiles $E$ and $F$, resulting in a material of lighter weight than that of the other tile, because of the burning out of the coal during kiln firing.

Ten each of tiles $A, B$, and $C$, and five each of the others were tested according to the Tentative Methods of Sampling and Testing Structural Clay Tile (C 112-35T) of the American Society for Testing Materials, ${ }^{1}$ insofar as these methods applied. The results of the tests are given in table 1 .

TABLE 1.-Physical properties of the structural clay tiles

Each value in the table is the average from tests of 10 tiles each of types $A, B$, and $C$, and of 5 tiles each of types $D, E, F$, and $G$.

\begin{tabular}{|c|c|c|c|c|c|c|c|c|c|c|c|}
\hline \multirow{2}{*}{ Type 1} & \multicolumn{3}{|c|}{ Dimensions } & \multirow{2}{*}{$\begin{array}{l}\text { Thick- } \\
\text { ness of } \\
\text { face } \\
\text { shells }\end{array}$} & \multicolumn{3}{|c|}{ Weight } & \multicolumn{2}{|c|}{$\begin{array}{l}\text { Compressive } \\
\text { strength (cells } \\
\text { vertical) }\end{array}$} & \multicolumn{2}{|c|}{ Absorption } \\
\hline & $\begin{array}{l}\text { Thick- } \\
\text { ness }\end{array}$ & Width & Length & & $\begin{array}{c}\text { Gross } \\
\text { volume }\end{array}$ & $\begin{array}{c}\text { Net } \\
\text { volume }\end{array}$ & $\begin{array}{l}\text { Per unit } \\
\text { of face } \\
\text { area }\end{array}$ & $\begin{array}{c}\text { Gross } \\
\text { area }\end{array}$ & $\begin{array}{l}\text { Net } \\
\text { area }\end{array}$ & $\begin{array}{l}\text { 24-hr } \\
\text { sub- } \\
\text { mersion }\end{array}$ & $\begin{array}{c}\text { 1-hr } \\
\text { boiling }\end{array}$ \\
\hline $\begin{array}{l}A \\
B \\
C \\
D \\
D \\
E^{2} \\
T^{2} \\
G\end{array}$ & $\begin{array}{l}\text { in. } \\
7.90 \\
7.95 \\
7.95 \\
7.90 \\
7.85 \\
7.80 \\
7.90\end{array}$ & $\begin{array}{l}\text { in. } \\
11.90 \\
12.00 \\
12.05 \\
11.90 \\
11.80 \\
11.95 \\
12.00\end{array}$ & $\begin{array}{l}\text { in. } \\
7.50 \\
7.50 \\
7.60 \\
7.50 \\
7.50 \\
7.50 \\
7.60\end{array}$ & $\begin{array}{l}\text { in. } \\
0.75 \\
1.50 \\
1.13 \\
1.37 \\
1.50 \\
1.40 \\
1.50\end{array}$ & $\begin{array}{r}\mathrm{lb} / \mathrm{ft}^{3} \\
51.0 \\
79.8 \\
59.1 \\
69.2 \\
53.5 \\
45.1 \\
60.3\end{array}$ & $\begin{array}{r}\mathrm{lb} / \mathrm{ft}^{3} \\
143 \\
141 \\
137 \\
140 \\
95 \\
92 \\
137\end{array}$ & $\begin{array}{r}\mathrm{lb} / \mathrm{ft}^{2} \\
33.42 \\
52.77 \\
39.11 \\
45.32 \\
35.24 \\
29.40 \\
39.68\end{array}$ & $\begin{array}{r}\text { Ib/in. }{ }^{2} \\
3,750 \\
5,300 \\
4,350 \\
4,000 \\
2,400 \\
2,000 \\
4,600\end{array}$ & $\begin{array}{r}\text { lb/in.2 } \\
10,600 \\
9,400 \\
10,050 \\
7,950 \\
4,300 \\
4,050 \\
10,400\end{array}$ & \begin{tabular}{r}
\multicolumn{1}{c}{$\%$} \\
2.91 \\
3.66 \\
3.88 \\
4.68 \\
10.44 \\
15.84 \\
5.40
\end{tabular} & $\begin{array}{r}\% \\
3.57 \\
4.17 \\
5.38 \\
5.78 \\
25.29 \\
27.56 \\
6.98\end{array}$ \\
\hline
\end{tabular}

1 Design of the tiles are illustrated in figures 1 and 2.

2Light-weight (highly porous) tile.

\section{BRICKS}

The bricks were of surface clay, formed by the stiff-mud side-cut process. Ten of the bricks, selected at random, were measured and tested according to the Tentative Methods of Testing Brick (C $67-35 \mathrm{~T}$ ) of the American Society for Testing Materials. ${ }^{2}$

\footnotetext{
i Proc. Am. Soc. Testing Materials 35, I, 807 (1935).

2 Proc. Am. Soc. Testing Materials 35, I, 791 (1935).
} 


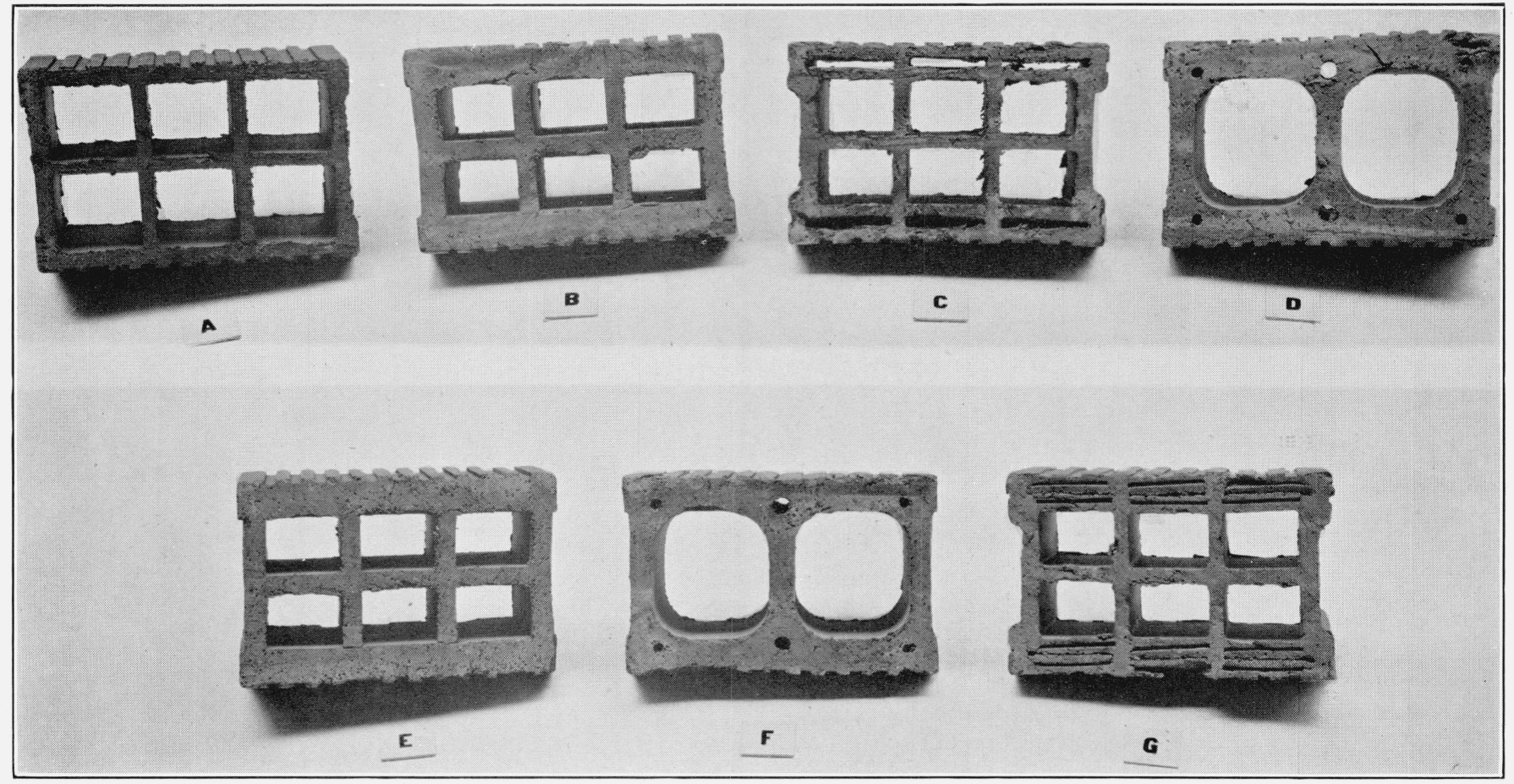

FIgURE 1.-Structural clay tiles.

Tiles $A$ were used in walls $A-1$ and $A-2 ; B$ in walls $B-1$ and $B-2$; and $C$ in walls $C-1$ and $C-2$. Tiles of each type were used in the wallettes according to the schedule given in table 3 . 


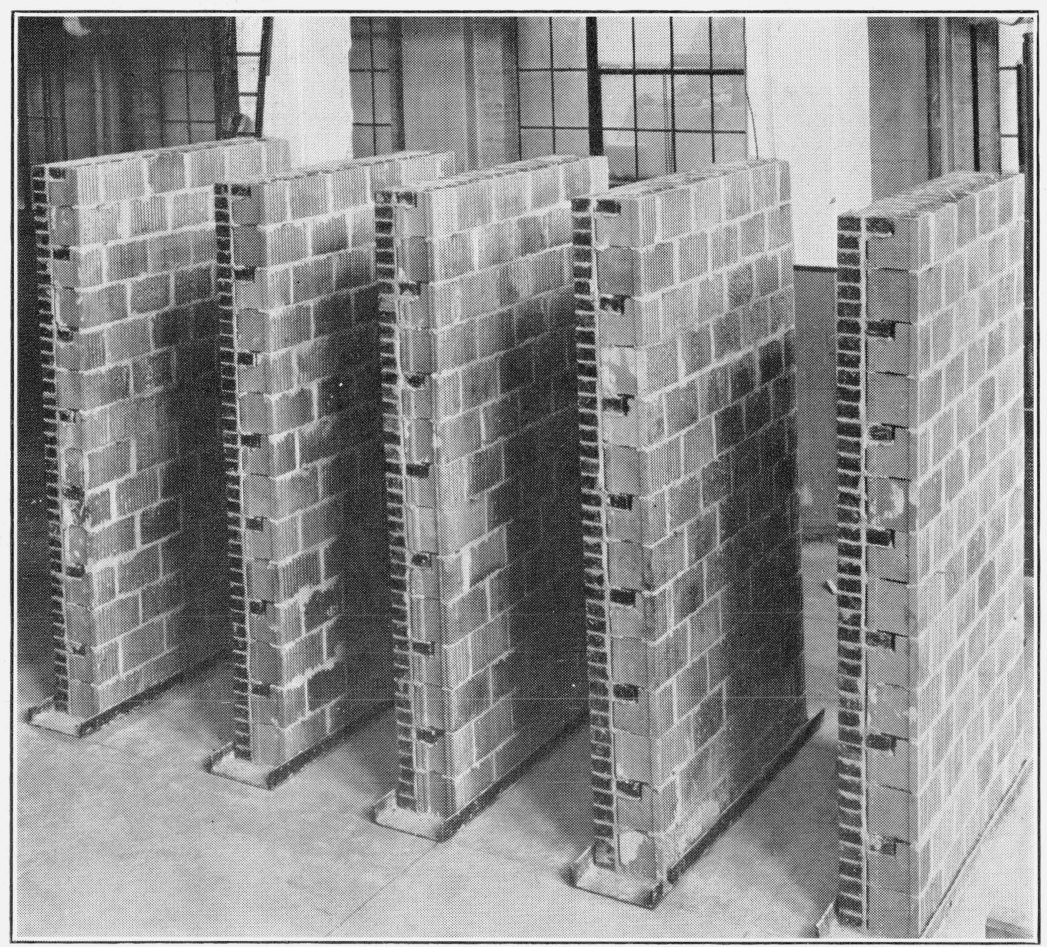

Figure 4.-View of five of the walls in the laboratory. 

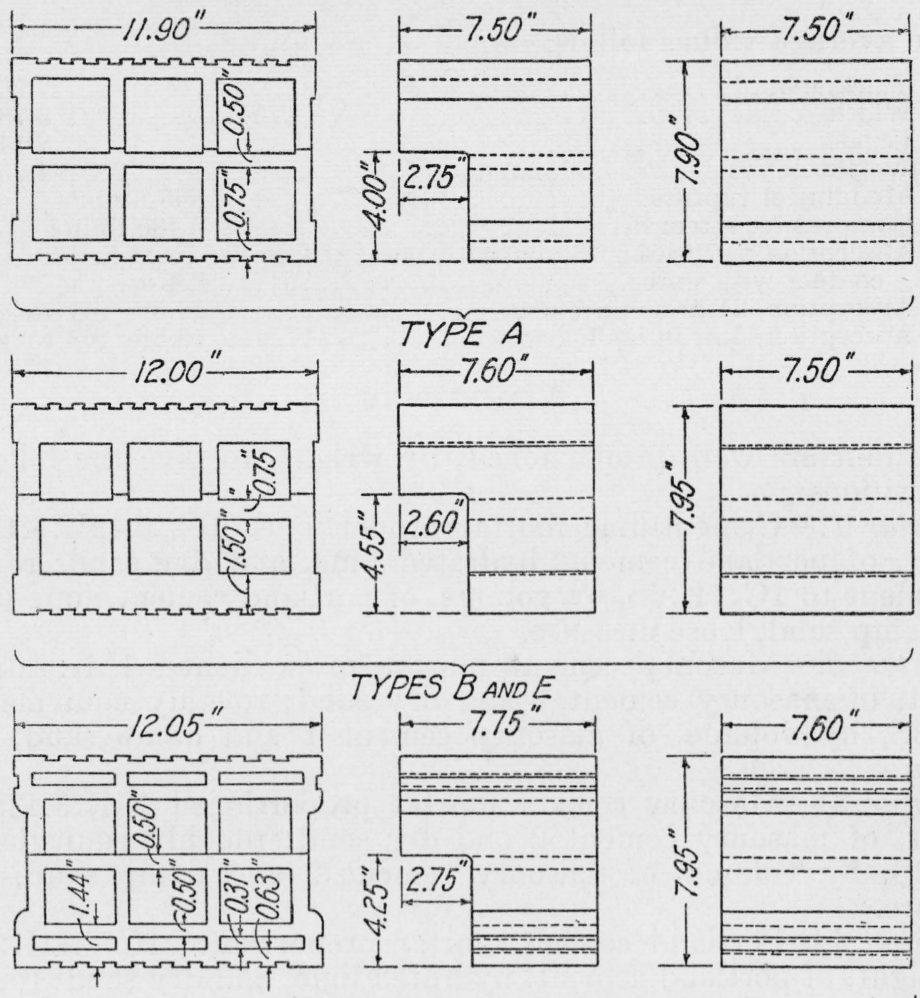

\section{TYPES B ANDE}
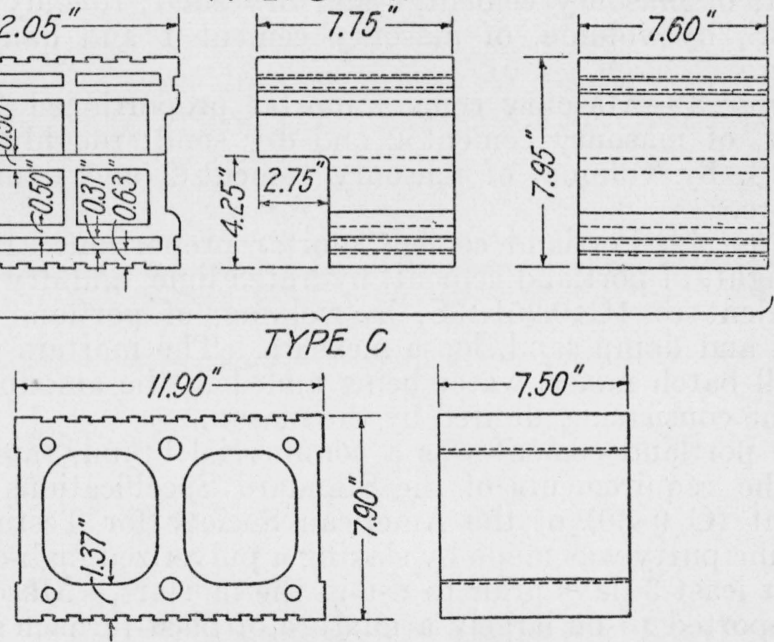

TYPES D ANDF
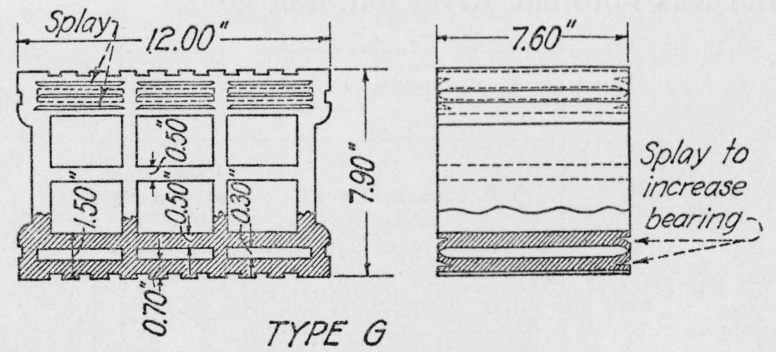

* No banding tile were used with types $D, E, F$ and $\theta$.

FIGURE 2.-Designs of tiles used in walls and walleties.

Tiles $A$ were used in walls $A-1$ and $A-2 ; B$ in walls $B-1$ and $B-2$; and $C$ in walls $C-1$ and $C-2$. Tiles of each type wero used in the wallettes according to the schedule given in table 3 . No bonding tile were used with types $D, E, F$, and $G$. Dimensions shown for tiles $E$ and $F$ are approximate; average values for each type of tile are given in table 1. 
The average values follow:

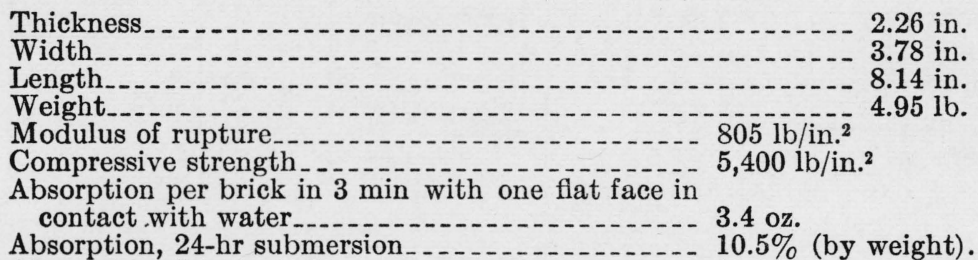

Absorption, $5 \mathrm{hr}$ in boiling water................

\section{MORTARS}

The mortars were proportioned, by weight, to give the following compositions:

Mortar 1.-Cement-lime mortar proportioned 1C: $0.42 \mathrm{~L}: 5.1 \mathrm{~S}$, by weight, of portland cement, hydrated lime, and dry sand; roughly equivalent to $1 \mathrm{C}: 1 \mathrm{~L}: 6 \mathrm{~S}$, by volume, of portland cement, lime putty, and damp sand, loose measure.

Mortar 2.-Masonry cement mortar proportioned $1 \mathrm{M}_{1}: 4.0 \mathrm{~S}$, by weight, of masonry cement 1 and dry sand; roughly equivalent to $1 \mathrm{M}_{1}: 3 \mathrm{~S}$, by volume, of masonry cement 1 and damp sand, loose measure.

Mortar 3.-Masonry cement mortar proportioned $1 \mathrm{M}_{2}: 3.43 \mathrm{~S}$, by weight, of masonry cement 2 and dry sand; roughly equivalent to $1 \mathrm{M}_{2}: 3 \mathrm{~S}$, by volume, of masonry cement 2 and damp sand, loose measure.

Mortar 4.-Portland cement mortar proportioned 1C:0.11L:2.6S, by weight, of portland cement, hydrated lime, and dry sand; roughly equivalent to $1 \mathrm{C}: 0.25 \mathrm{~L}: 3 \mathrm{~S}$, by volume, of portland cement, lime putty, and damp sand, loose measure. The mortars were mixed in a small batch mixer, water being added in the amounts required to give the consistency desired by the mason.

The portland cement was a commercial brand, samples of which met the requirements of the Standard Specifications for Portland Cement (C 9-30) of the American Society for Testing Materials. ${ }^{3}$ The lime putty was made by slaking a pulverized high-calcium quicklime at least 3 days prior to use in the mortars. Masonry cement 1 was reported to be largely a mixture of blast-furnace slag and lime, and masonry cement 2 as a mixture of portland and natural cements. The sand was Potomac River building sand.

\begin{tabular}{|c|c|}
\hline \multicolumn{2}{|c|}{$\begin{array}{l}\text { Size distribution of Potomac River building } \\
\text { sand }\end{array}$} \\
\hline U. S. Standard Sieve no. & $\begin{array}{c}\text { Percentage } \\
\text { passing (by } \\
\text { weight) }\end{array}$ \\
\hline $\begin{array}{l}4 \\
8 \\
16 \\
30 \\
50 \\
100\end{array}$ & $\begin{array}{r}100.0 \\
99.4 \\
94.4 \\
75.2 \\
14.0 \\
1.0 \\
0.5\end{array}$ \\
\hline
\end{tabular}

3 1930 Book of ASTM Standards, II, 3. 
The cementing materials used in each of the mortars were tested according to the methods of Federal Specification for Masonry Cement (SS-C-181). All met the requirements of this specification. The compressive strengths of the 2-inch cubes of mortar, 1:3, by weight of cementing material to sand and having a flow of $105 \pm 5$ percent, were as follows:

\begin{tabular}{|c|c|c|}
\hline \multirow{2}{*}{$\begin{array}{c}\text { With cement for } \\
\text { mortar }\end{array}$} & \multicolumn{2}{|c|}{$\begin{array}{c}\text { Compressive strength } \\
\text { at- }\end{array}$} \\
\cline { 2 - 3 } & 7 days & 28 days \\
\hline & & \\
& $1 \mathrm{~b} / \mathrm{in}^{2}$ & $1 \mathrm{~b} / \mathrm{in.}^{2}$ \\
& 790 & 1,120 \\
& 400 & 660 \\
2 & 810 \\
4 & 410 & 8100 \\
\hline
\end{tabular}

The average compressive strengths of 2 -inch cubes molded from the mortars used in the walls and wallettes and aged in the damp-storage room of the concrete laboratory until tested were as follows:

\begin{tabular}{|c|c|c|}
\hline \multirow{2}{*}{ Mortar } & \multicolumn{2}{|c|}{$\begin{array}{c}\text { Compressive strength } \\
\text { at- }\end{array}$} \\
\cline { 2 - 3 } & 7 days & 28 days \\
\hline & & \\
\hline & $1 \mathrm{~b} /$ in. $^{2}$ & $1 \mathrm{~b} / \mathrm{in.}^{2}$ \\
360 & 1,040 \\
1 & 340 & 1,110 \\
2 & 670 \\
\hline & 360 & 670 \\
\hline
\end{tabular}

\section{WALLS AND WALLETTES}

\section{DESCRIPTION OF WALLS}

(a) TYPES

The walls were a combination of brick facing and tile backing with a masonry bond, as illustrated in figure 3 . Figure 4 shows five of the walls, and figure 5 shows typical sections of the walls and wallettes. The walls were approximately $9 \mathrm{ft}, 3 \mathrm{in}$. high; $5 \mathrm{ft}, 1 \mathrm{in}$. long; and 12.3 in. thick. Two walls each were constructed of tiles $A, B$, and $C$. Mortar 1 (proportions 1:0.42:5.1 of portland cement, hydrated lime, and sand) was used in all walls.

\section{(b) WORKMANSHIP}

A contract for building the walls was let, for a lump sum, to a masonry contractor whose workmen were experienced in the construction of masonry walls.

The walls were constructed on structural-steel channels. The channels were leveled before starting construction, and the walls were kept plumb and the courses level as the work progressed. The bricks were wetted before laying; the tiles were dry. The mortar for the bed joints in the brickwork was spread to uniform thickness (not furrowed). Mortar was applied to the ends of stretcher bricks and to the edges of header bricks before laying; after laying, the filling of the cross joint was completed (if necessary) by "slushing." The facing between two 
consecutive header courses was constructed, and the back surface coated with a mortar parging about $3 / 8$ in. thick before setting the tile of the backing. Except for the bed of the header brick, the mortar in the tile backing was applied only along the face shells, as illustrated in figures 3 and 5 .

\section{(c) AGING}

The walls were built during the period from November 27 to December 4,1935 , and remained in the laboratory until tested at ages ranging from 57 to 62 days.

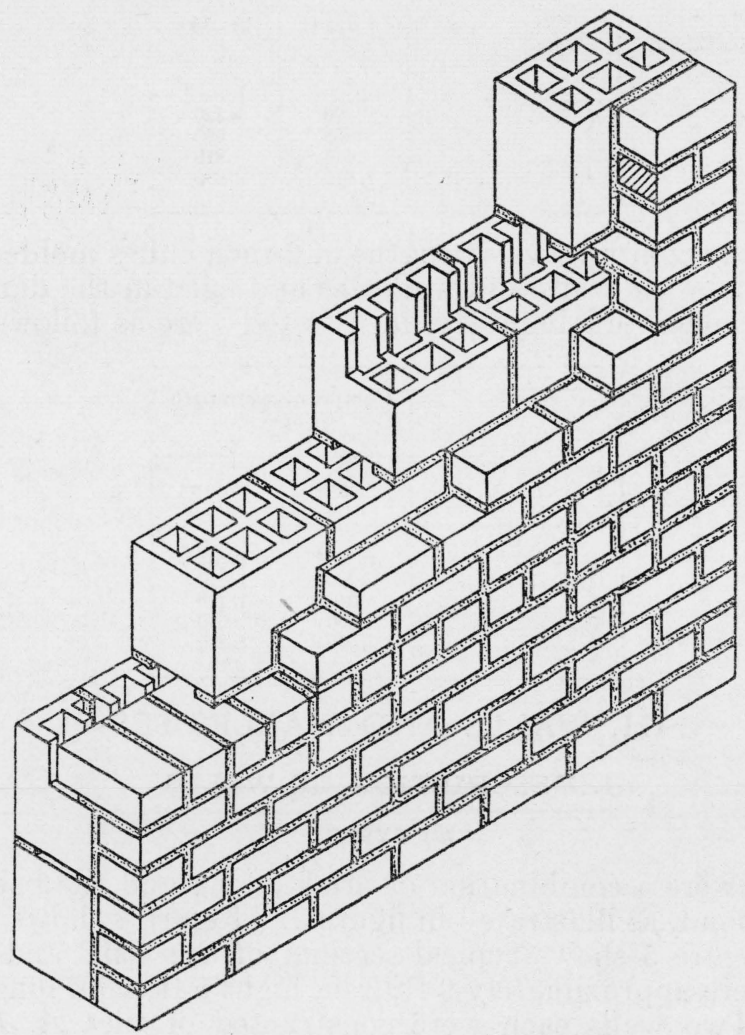

FIgURE 3.-Details of the walls.

Joints in the brick facing were filled with mortar and the back of the stretcher bricks of the facing was parged with mortar. The mortar was spread only along the two face shells of the tiles.

\section{DESCRIPTION OF WALLETTES}

(a) TYPES

Each wallette consisted of three tiles set on end with their faces and cells in alignment, as illustrated in figure 5. The wallettes were approximately $2 \mathrm{ft}$ high, $1 \mathrm{ft}$ long, and $7.9 \mathrm{in}$. thick. Only two shells on opposite faces of each tile were bedded in mortar. Using mortar 1 , three wallettes each were constructed of tiles $A, B, C, D, E, F$, and $G$. In addition, there were three wallettes each of tile $B$ made with each of mortars 2,3 , and 4 . 
(b) AGING

The wallettes were constructed in the laboratory and were kept until tested (2 months) in a room in which the temperature of the air was maintained at $70 \pm 2^{\circ} \mathrm{F}$. The tiles were dry when set. The wallettes were built during the month of January 1936. The extraordi-

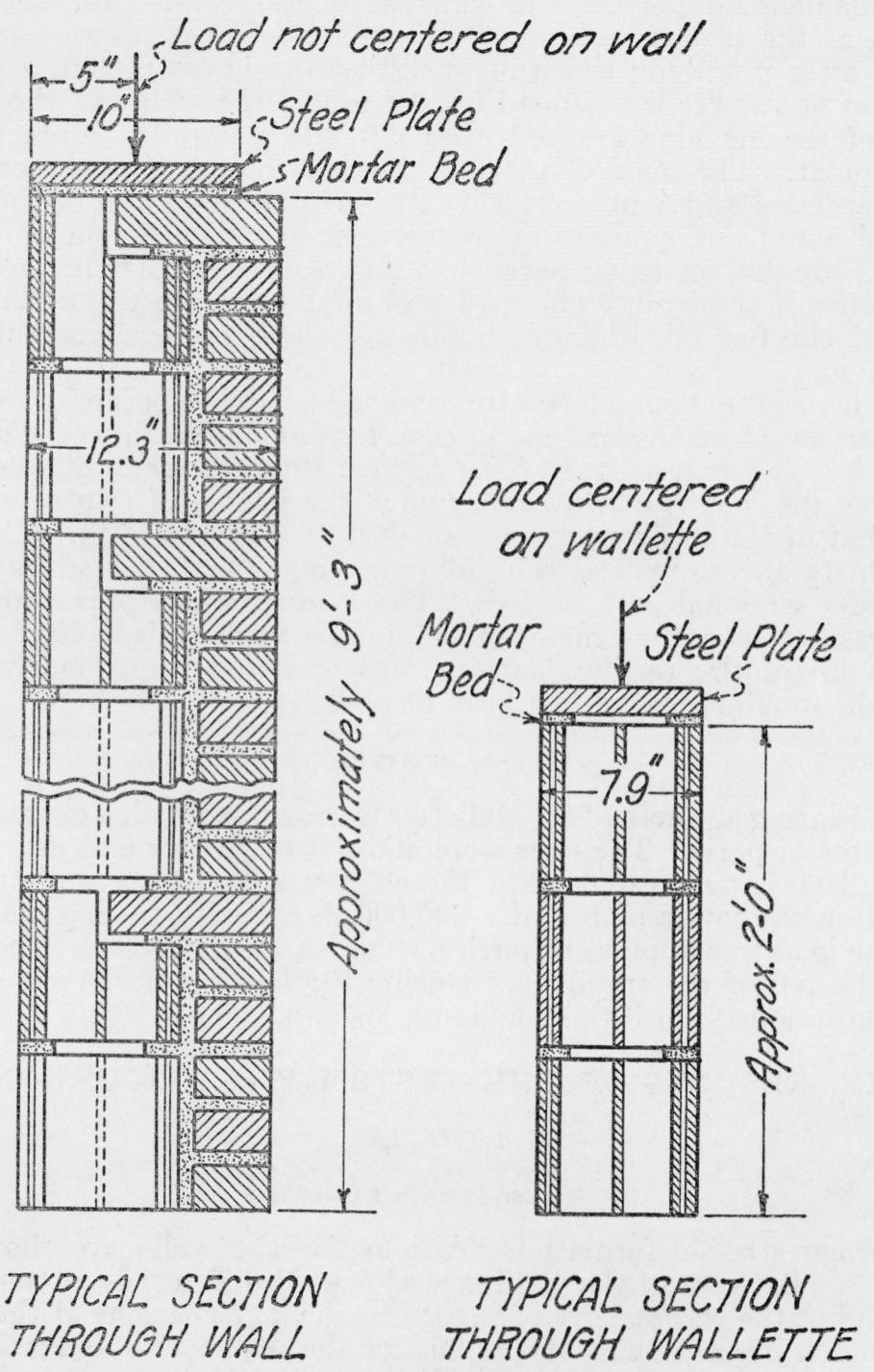

Figure 5.-Typical sections of walls and wallettes.

narily cold weather and the attendant low relative humidity in the storage room during the aging, together with the free circulation of air around the specimens, probably produced an abnormally rapid drying of the mortar in the wallettes. The highly unfavorable curing conditions would be expected to result in strengths lower than normal, especially for mortars 2,3 , and 4 , as these were of compositions which would tend to dry more rapidly than mortar 1 . 


\section{METHODS OF TESTING}

\section{(a) WALLS}

The walls were tested in compression under eccentric loading in the 10,000,000-lb capacity machine at the National Bureau of Standards. The channels supporting the walls were first bedded on the lower platen of the testing machine in a mortar of neat plaster of paris. Then, after plumbing the wall by tilting the lower platen, a cap of the plaster mortar was spread on the top of the wall and the upper head of the machine lowered until it made a uniform contact with the mortar. The head of the machine was raised after the capping had hardened and a plane steel plate was placed on top of the wall. A steel bar, $5 / 16$ in. square in cross section, was then set on the plate, the axis of the bar being parallel to and a distance of 5 in. from the back face of the wall. The load was applied to the top of the wall through this bar, resulting in a compressive load having an eccentricity of $1.15 \mathrm{in}$.

Vertical compressometers were attached near each corner of the wall and horizontal extensometers on each face at midheight, as shown in figure 6. The gage length of the vertical compressometers (about 95 in.) was the height of the wall, minus the height of two courses of tile; that of the horizontal extensometers was about $45 \mathrm{in}$. The dial micrometers were read at each $50-1 b / i n .{ }^{2}$ increment of load based on the gross sectional area of wall. The loading was stopped and the compressometers were removed before the walls failed, after which the pump of the testing machine was operated continuously until after the maximum load had been passed.

\section{(b) WALLETTES}

The bearing surfaces of the wallettes were capped with a neat mortar of plaster of paris. The caps were allowed to harden and dry before the wallettes were tested. For the compressive tests a wallette was placed on the lower platen of a 300,000-lb capacity testing machine, and the load was applied through a spherical bearing block in contact with the top of the specimen. During the loading the machine was run continuously until the maximum load was passed.

\section{RESULTS OF THE TESTS WITH DISCUSSION}

\section{WALLS}

\section{(a) STRESS-STRAIN DIAGRAMS}

Average stress-deformation relations for the walls are shown in figure 7. Because of the combined effects of differences in construction and of the eccentricity of the loads, the deformations at the back were much greater than at the face of the walls. The stress-strain diagrams for the back are decidedly curved with the rate of increase of strain becoming larger as the stress increased, even for loads below one-half of the maximum load for the walls. In this respect these curves show relations similar to those found in other tests of masonry built with lime mortar or comparatively weak cement-lime mortars. ${ }^{4}$

\footnotetext{
- See, for example: BS Tech. Pap. 20, 338 (1926) T311; BS J. Research 3, 532 (1929) RP108.
} 


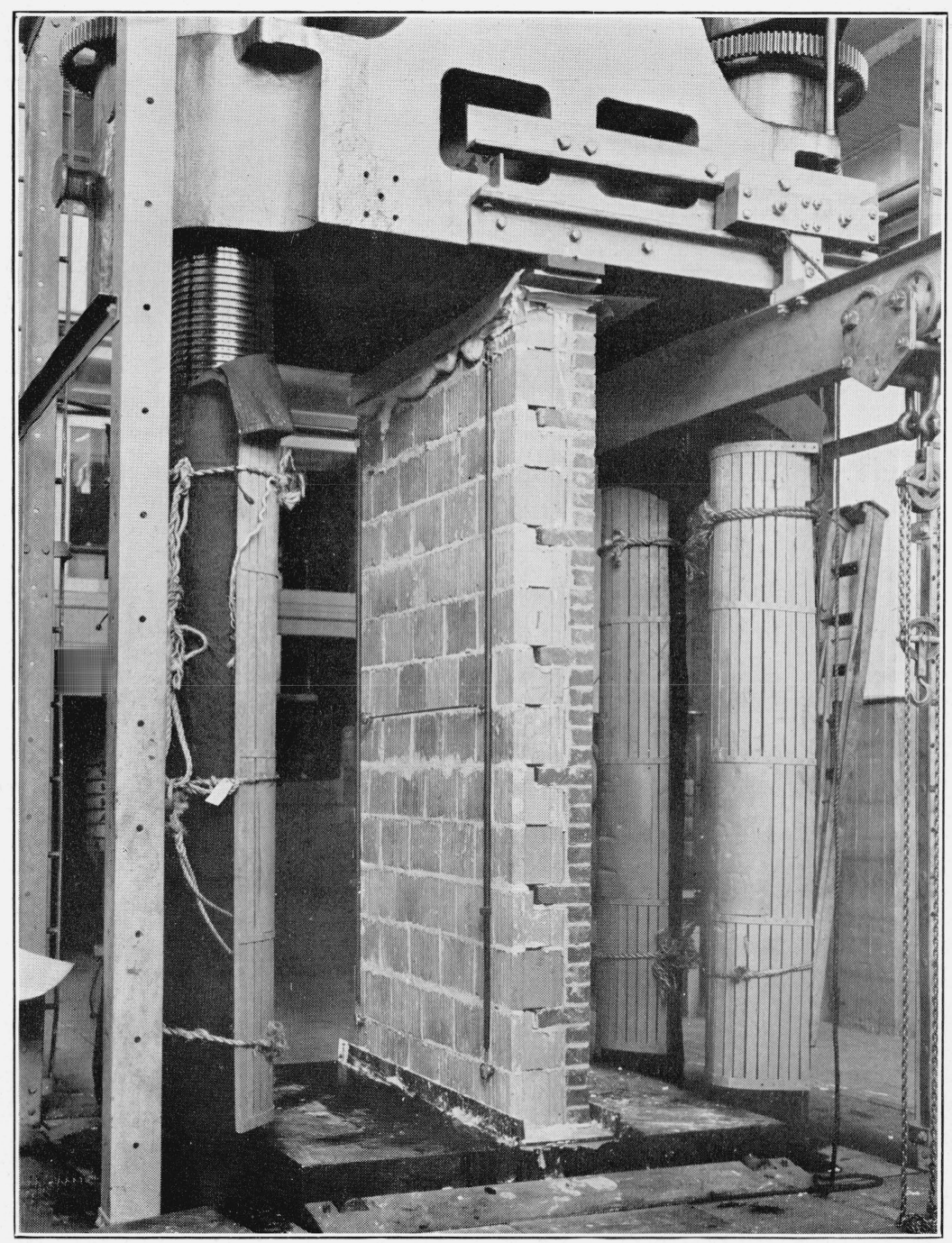

FIGURE 6.-Wall $C-1$ in the testing machine ready for compressive test, eccentric loading. 
(b) BEHAVIOR UNDER LOAD

The mortar in the bed joints of the tile backing crushed as the loads approached the maxima. Usually the crushing of the mortar was evident before any other sign of impending failure. This was fol-
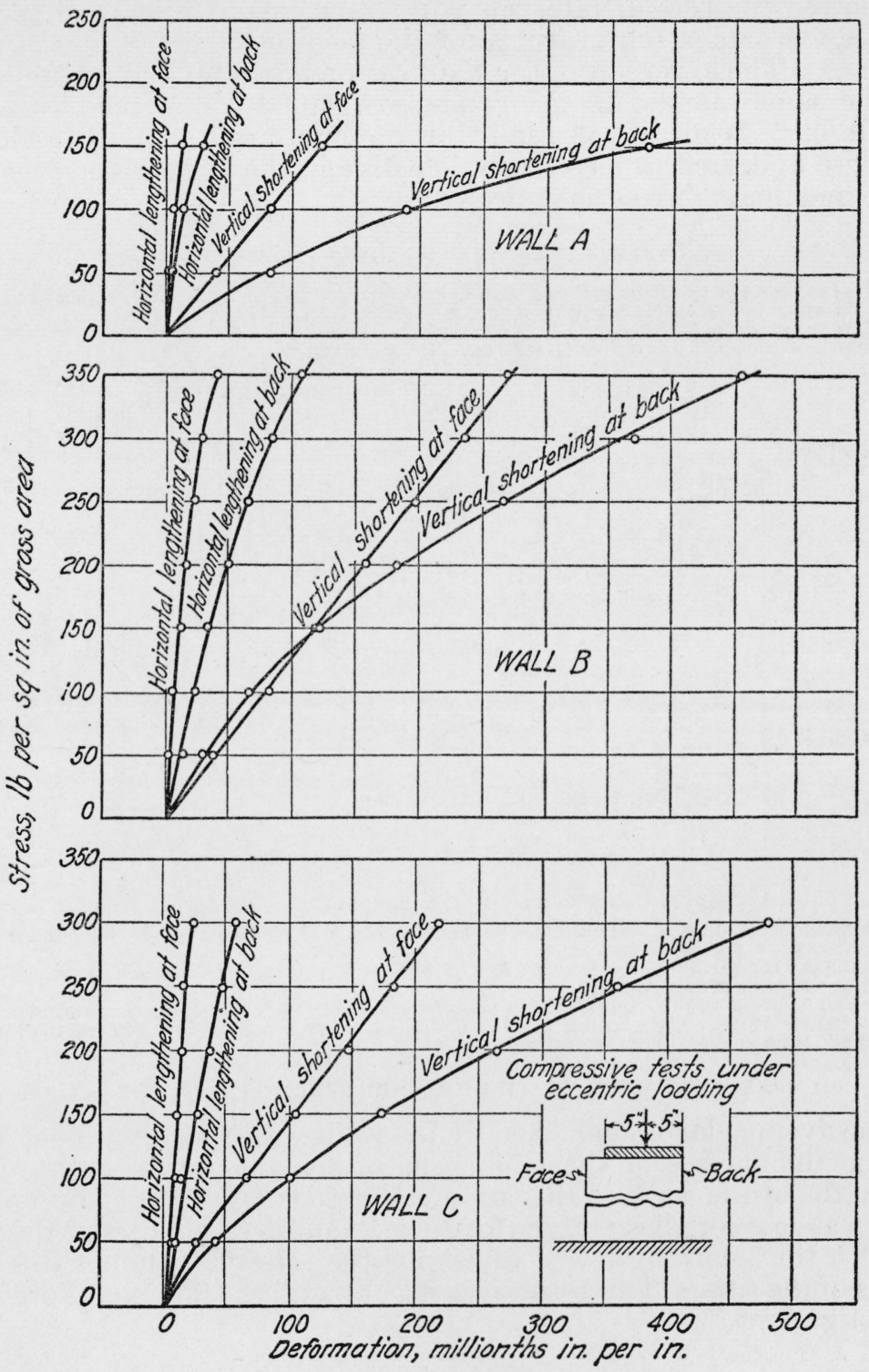

FiguRE 7.-Stress-deformation relations for the walls.

lowed by the appearance of vertical cracks in some of the tiles and sometimes by vertical cracks in the header bricks between the facing and backing. 


\section{(c) COMPRESSIVE STRENGTH}

The compressive strengths of the walls are given in table 2. Wall $C-1$ failed when the average stress was $335 \mathrm{lb} / \mathrm{in} .{ }^{2}$ The damaged portion of the wall was confined to the upper two courses of tile. Upon removing these courses, it was observed that the mason had supported the tiles at intervals with fragments of brick and tile and had not provided full bearings for the face shells of the tiles of these courses. The lower $8 \mathrm{ft}$ of the wall was prepared for test and reloaded in the same manner as before and withstood a maximum stress of $480 \mathrm{lb} /$ in. $^{2}$ Wall $A-1$ also failed in the upper two courses of tile and likewise appeared to have been defective in the same manner as wall $C-1$, but this wall was not retested.

TABLE 2.-Compressive strength of the walls.

Walls of end-construction structural clay tile and brick facing, $9 \mathrm{ft}, 3 \mathrm{in}$. high; $5 \mathrm{ft}, 1 \mathrm{in}$. long; and $12.3 \mathrm{in}$. thick. Mortar, 1C:0.42L:5.1S, by weight, of portland cement, hydrated lime, and sand.

Walls tested at ages of 57 to 62 days.

Compressive load applied at top of wall with eccentricity of $1.15 \mathrm{in}$.

\begin{tabular}{|c|c|c|c|c|c|}
\hline \multirow{2}{*}{$\begin{array}{l}\text { Designation of } \\
\text { wall }\end{array}$} & \multicolumn{3}{|c|}{ Tiles } & \multirow{2}{*}{$\begin{array}{l}\text { Weight of } \\
\text { walls per } \\
\text { unit of } \\
\text { face area }\end{array}$} & \multirow{2}{*}{$\begin{array}{l}\text { Compres- } \\
\text { sive } \\
\text { strength } 1\end{array}$} \\
\hline & $\begin{array}{l}\text { Desig- } \\
\text { nation }\end{array}$ & Description & $\begin{array}{c}\text { Thick- } \\
\text { ness of } \\
\text { face shells }\end{array}$ & & \\
\hline$A-1, \ldots . . . . .$. & $\stackrel{A}{A}$ & \}6-cell, 8 by 12 by $71 / 2$ (standard). & $\left\{\begin{array}{r}\text { in. } \\
0.75 \\
.75\end{array}\right.$ & $\begin{array}{r}\mathrm{lb} / \mathrm{ft}^{2} \\
88 \\
88\end{array}$ & $\begin{array}{r}\text { lb/in. }{ }^{2} \\
2235 \\
320\end{array}$ \\
\hline Average... & - & & - & 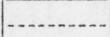 & 280 \\
\hline 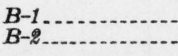 & $\begin{array}{l}B \\
B\end{array}$ & \}-cell, 8 by 12 by $71 / 2$ (thick shells). & $\left\{\begin{array}{l}1.50 \\
1.50\end{array}\right.$ & $\begin{array}{l}100 \\
100\end{array}$ & $\begin{array}{l}655 \\
590\end{array}$ \\
\hline Average... & (n.... & & . & -.... & 620 \\
\hline$C-1, \ldots$ & $\begin{array}{l}C \\
C\end{array}$ & Double shell, 8 by 12 by $71 / 2 \ldots$ & $\begin{array}{l}1.12 \\
1.12\end{array}$ & $\begin{array}{l}92 \\
92\end{array}$ & $\begin{array}{r}835 \text { or } \\
480 \\
450\end{array}$ \\
\hline Average... & -..... & & & & $\begin{array}{rl}3 & 390 \text { or } \\
465\end{array}$ \\
\hline
\end{tabular}

1 The compressive strength was calculated as the maximum load supported by the wall divided by the gross cross-sectional area of the wall.

2 The upper 2 courses of wall $A-1$ were not well bedded and fragments of tile and brick were found, after the test, in the joints of these courses.

3 The first failure of wall $C-1$ appeared to be premature and to be caused by defective construction in the upper 2 courses of tile. These courses failed at $335 \mathrm{lb} / \mathrm{in}^{2}$. After removing these courses, the wall was retested and supported $480 \mathrm{lb} / \mathrm{in} .^{2}$ before failure.

\section{(d) EFFECT OF KIND OF TILE ON THE STRENGTH OF THE WALLS}

The average loads supported by the walls were roughly proportional to the thicknesses of the face shells of the tiles. The ratio of the strengths of the walls to the compressive strengths (gross area) of the tiles was less for tiles $C$ than for tiles $B$, and less for tiles $A$ than for tiles $C$, thus showing lower values for the ratio, the thinner the face shells of the tiles. This result is in accord with the findings of previous investigations. ${ }^{5}$

\section{WALLETTES}

\section{(a) BEHAVIOR UNDER LOAD}

The crushing of the mortar in the joints was usually the first evidence of impending failure of the wallettes built with mortars 2 and 3 . This was followed by the appearance of vertical cracks in the tiles.

\footnotetext{
5 J. Research NBS 6, 857 (1931) RP310.
} 
Although the crushing of mortar in tile masonry is not always apparent, even when an examination after failure shows that the mortar has failed, some spalling was noticed with some of the specimens built with mortar 1. Examinations of fragments of mortars 1 and 4 from the joints, after the tests, indicated that the mortars either were abnormally weak or had been partially crushed.

\section{(b) COMPRESSIVE STRENGTH}

The results of the compressive tests of the wallettes are given in table 3.

\section{TABLE 3.-Compressive strength of the wallettes}

Each wallet te consisted of 3 tiles set on end with only the 2 face shells bedded in mortar. Wallettes tested in compression at the age of 2 months

\begin{tabular}{|c|c|c|c|c|c|c|}
\hline \multirow{2}{*}{ Tile } & \multirow{2}{*}{ Mortar } & \multicolumn{4}{|c|}{ Compressive strength (gross area) } & \multirow{2}{*}{$\begin{array}{l}\text { Average } \\
\text { compressive } \\
\text { strength } \\
\text { (bedded } \\
\text { area) }\end{array}$} \\
\hline & & Specimen 1 & Specimen 2 & Specimen 3 & Average & \\
\hline D & $\begin{array}{l}1 \\
1 \\
1 \\
1 \\
1\end{array}$ & $\begin{array}{r}\text { lb/in. }{ }^{2} \\
500 \\
520 \\
1,010 \\
520 \\
750\end{array}$ & $\begin{array}{r}\text { lb/in. }{ }^{2} \\
435 \\
695 \\
1,655 \\
570 \\
810\end{array}$ & $\begin{array}{r}\text { lb/in. }{ }^{2} \\
605 \\
610 \\
1,470 \\
855 \\
850\end{array}$ & $\begin{array}{r}\text { lb/in. }{ }^{2} \\
510 \\
610 \\
1,380 \\
650 \\
800\end{array}$ & $\begin{array}{l}\text { lb/in. }{ }^{2} \\
2,680 \\
2,160 \\
3,960 \\
1,710 \\
2,220\end{array}$ \\
\hline $\begin{array}{l}G \\
B \\
B\end{array}$ & $\begin{array}{l}1 \\
1 \\
2 \\
3 \\
4 \\
\end{array}$ & $\begin{array}{r}405 \\
1,370 \\
705 \\
475 \\
1,620 \\
\end{array}$ & $\begin{array}{r}510 \\
1,110 \\
705 \\
530 \\
1,110 \\
\end{array}$ & $\begin{array}{r}445 \\
1,435 \\
605 \\
455 \\
1,350 \\
\end{array}$ & $\begin{array}{r}450 \\
1,300 \\
670 \\
490 \\
1,360 \\
\end{array}$ & $\begin{array}{r}1,200 \\
3,440 \\
1,780 \\
1,300 \\
3,600 \\
\end{array}$ \\
\hline
\end{tabular}

The values of compressive strength (gross area) were obtained by dividing the maximum load on a wallette by the product of the length and width of the tile. The ratios of the strengths of walls $A, B$, and $C$ to the strengths, respectively, of wallettes with tiles $A, B$, and $C$ and mortar 1 , were $0.55,0.48$, and 0.64 . This rather wide range in the ratios indicates that the strengths of the wallettes did not provide a close measure of the strengths of the walls.

Nevertheless, the strengths of the wallettes may provide an indication of relative efficiencies of some of the designs of the tile. Comparing the strengths of the wallettes of tiles of approximately equal weights, it is seen that tiles $D$ were more efficient than tiles $B$ and tiles $F$ than tiles $E$. The splaying of the ends of the shells of tiles $G$ apparently was not of advantage as the strengths of the wallettes of tiles $G$ were less than for those of the otherwise similar tiles $C$.

As previously mentioned, the curing conditions for the mortar in the wallettes were unfavorable in that the joints were exposed to rapid drying. The small volume of mortar in the wallettes was exposed to the free circulation of air of low relative humidity and, therefore, dried more rapidly than the mortar joints in larger specimens of masonry. Mortar 1, which contained a relatively large amount of a plastic lime putty of high water retentivity, probably dried less rapidly than the others, and, accordingly, hardened at a rate nearer to normal. Under these conditions the strengths of the wallettes probably do not afford reliable estimates of the relative strengths of large specimens of masonry with the four mortars used. The data in Technologic Paper T311 indicate that, for large walls of end-construction tile, the strength of the walls was approximately proportional to the square root of the 
compressive strength of the mortar cylinders. ${ }^{6}$ Similarly, it has been found that the strengths of solid walls of brick are approximately proportional to the cube root of the strengths of the mortars. ${ }^{7}$ In contrast with these results obtained for large walls, the strengths of the wallettes with mortar 4 were only slightly greater than with the much weaker mortar 1. It may be concluded, therefore, that the conditions were relatively not as favorable for the wallettes with mortar 4 as for those with the other mortars which normally develop much lower strengths.

\section{CONCLUSIONS}

1. Behavior under load of the walls of end-construction tile and brick showed failure of the mortar in the bed joints of the tile before failure of other portions of the walls. This was evidenced by the increasing rate of deformation with increasing loads and by the crushing of the mortar at the back face of the walls.

2 . Strengths of the walls were roughly proportional to the thickness of the face shells of the tiles.

3. Average compressive strengths of the wallettes composed of three tiles with their face shells bedded in mortar ranged from 450 to $1,380 \mathrm{lb} / \mathrm{in}^{2}$ of gross cross-sectional area.

4. Crushing of the bed joints was the first sign of impending failure for the wallettes with mortars of masonry cement and sand. Some crushing of these joints was observed also with the cement-lime and the cement mortars. Although the curing conditions for the mortars were believed to be unusually unfavorable, strengths of the wallettes with masonry cement mortars were much lower than for those with the cement-lime mortars.

5. Although there was a marked tendency for the strengths of the wallettes to increase with thickness of the face shells of the tiles, this relation was not as uniform as was found with the data for the walls.

6. Wallettes of the tiles having two oval cores were stronger than those of six-cell tiles of about the same weight. Wallettes of tiles $G$, the ends of the shells of which were splayed to provide a large bearing area, were not as strong as those of otherwise similar tiles $C$ of doubleshell design.

The Housing Division assisted in defraying the cost of the investigation, and the structural section of that Division, A. M. Korsmo, principal structural engineer, planned the investigation and designed the specimens. The tiles were donated by the National Fireproofing Corporation, and the bricks were donated by the Locher Brick Co.

Acknowledgment is made also of the assistance of C. C. Fishburn, who supervised the construction of the walls, and of Messrs. L. R. Sweetman and C. W. Ross, who assisted in the testing of the walls.

Washington, December 18, 1936.

o Tech. Pap. BS 20, 352 (1926) T311.

7J. Research NBS 3, 546 (1929) RP108. 